\title{
DISTRIBUTION OF CALCAREOUS ALGAE, ONCOLITES AND STROMATOLITES IN WENLOCK-LUDLOW BOUNDARY BEDS IN ESTONIA
}

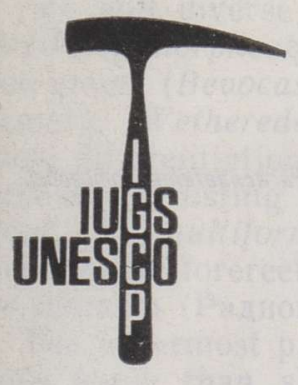

GLOBAL BIOEVENTS

Silurian calcareous algae are known from many localities, including Gotland (Rothpletz, 1913; Riding, 1979), Quebec-Gaspé (Bourque et al., 1981) and Podolia (Ищенко, 1985), the algal assemblages of which are somewhat similar to those of Estonia (Радионова, Эйнасто, 1986; 1988).

The present paper deals with the stratigraphic distribution of calcareous algae in Wenlock-Ludlow boundary beds in the Saaremaa sequence and is based on previously reported data by E. Radionova, $\mathrm{R}$. Einasto and in a minor part on the data (Lahetaguse, Mõnnuste, Soeginina) by the author. However, to reveal the event-stratigraphic significance of calcareous algae, more thorough studies are needed.

The sequences depicted in Figs. 1 and 2 comprise the shallowest water, i.e. shoal and lagoonal Wenlock and Ludlow deposits of Saaremaa. Although the calcareous algae found in these sections in the interval between the lundgreni and leintwardiensis zones are mostly long-ranging, their distribution is of a complicated pattern correlative to facies diversity. The latter reflects the general sea level lowering at the end of the Wenlock, as well as local environmental changes like drop of salinity (ЭйнасTo, 1968). Calcareous algae have been recorded from shoal deposits (skeletal or pelletal grainstones and packstones). They do not occur or have not been preserved in sedimentary dolostones containing instead non-calcified phaeophyte? algae not studied in Estonia but recorded from many other regions (e.g. Podolia).

The algal affinity of some genera mentioned here is not unequivocally approved, however, this problem is not discussed below.

As the studied sequences did not yield graptolites, the correlation with graptolite zones depicted in Fig. 1 was compiled using data by D. Kaljo (1990, Table 2).

\section{General distribution patterns.}

Following the diversity characteristics, two different calcareous algal floras can be distinguished in the Wenlock-Ludlow sequence on Saaremaa. The taxonomic diversity and abundance of calcareous algae are the greatest in Wenlock reef and reef-surrounding deposits (Vilsandi $-J_{2} V$ and Maasi - $\mathrm{J}_{2} \mathrm{M}$ beds, Fig. 1), as various major algal groups - cyanophytes, rhodophytes, chlorophytes - are represented.

* Eesti TA Geoloogia Instituut (Institute of Geology, Estonian Academy of Sciences), Estonia pst. 7, 200105 Tallinn, Estonia. 


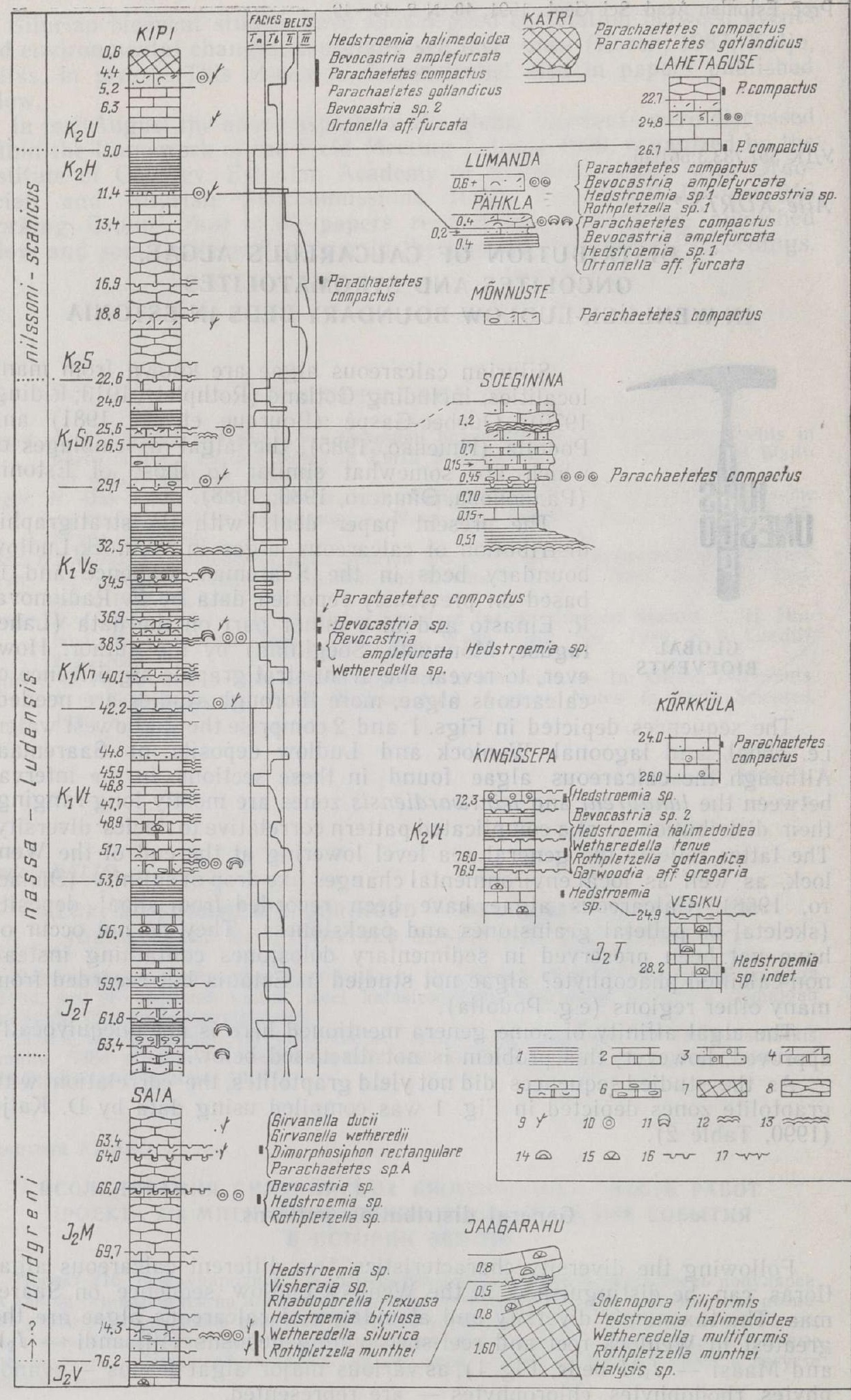


The algal diversity in the Ludlow reef (Sauvere - $\mathrm{K}_{2} \mathrm{~S}$ and Uduvere $\mathrm{K}_{2} \mathrm{U}$ beds) and restricted shelf deposits is not so great as in the Wenlock. Ludlow flora is dominated by red algae.

Calcareous algae seem to be extremely rare in the Vesiku Beds $(K, V s)$ - only two finds have been recorded. At the same time, the Vesiku Beds are noteworthy for the lateral distribution maximum of oncolites and stromatolites (Fig. 2).

Below some more or less distinct changes in the stratigraphic distribution of algae, oncolites and stromatolites are treated.

\section{Calcareous algae}

The algal assemblage of the Vilsandi $\left(\boldsymbol{J}_{2} \boldsymbol{V}\right)$ and Maasi $\left(\boldsymbol{J}_{2} \boldsymbol{M}\right)$ beds is rich and diverse comprising green dasyclad and codiacean (Rhabdoporella, Dimorphosiphon, Hedstroemia), red (Solenopora, Parachaetetes), blue-green (Bevocastria, Rothpletzella, Girvanella) and somewhat problematic (Wetheredella) algae. Both framebuilders and encrusters occur. Some differentiation can be noticed between the fore- and backreef algal content: encrusting Solenopora filiformis Nicholson, Wetheredella silurica Wood, W. multiformis A. Ishchenko and Rothpletzella munthei Wood occur in the forereef, while in the backreef bushy forms like Hedstroemia are common (Радионова, Эйнасто, 1986).

The lowermost part of the Tagavere Beds $\left(\boldsymbol{J}_{2} \boldsymbol{T}\right)$ should perhaps reveal more algae than shown in Fig. 1, but up to now only two finds of Hedstroemia have been recorded: Hedstroemia halimedoidea Rothpletz from the Kingissepa and Hedstroemia sp. from the Vesiku core.

The lower unit of the Viita Beds $\left(\boldsymbol{K}_{1} \boldsymbol{V} t\right)$ contains a diverse assemblage resembling in its diversity the underlying Vilsandi and Maasi beds, but in addition some new species - Wetheredella tenue Radionova, Rothpletzella gotlandica Wood, Garwoodia aff. gregaria (Nicholson) have been distinguished.

The Kuusnõmme Beds $\left(\boldsymbol{K}_{1} \boldsymbol{K} \boldsymbol{n}\right)$ have yielded few algae, but there occur Bevocastria amplefurcata and Parachaetetes compactus (Rothpletz) (Kuusnõmme outcrop; Plate I, 1) which are more characteristic of the overlying part of the Silurian sequence in Estonia. Morphological diversity of Bevocastria and Parachaetetes, and whether it is due to environmental factors or specific differences, should be studied separately. Parachaetetes compactus and $P$. gotlandicus are present in the Vattenfallet section of Gotland already in the Upper Visby Marl and Högklint "C" (Riding, 1979), but they gain predominance in Ludlow assemblages.

In the Vesiku Beds $\left(\boldsymbol{K}_{1} \boldsymbol{V} \boldsymbol{s}\right)$ algae are very rare. Parachaetetes compactus (Plate I, 2) and Bevocastria sp. are found in its basal part in the Kipi core.

Fig. 1. Distribution of calcareous algae in some selected sections of Saaremaa (lithological columns and facies curve by R. Einasto). 1 - lagoonal sedimentary dolostone; 2 - restricted shelf limestone and secondary dolostone; 3 - pelletal and oolite grainstones of shoal; 4 - skeletal grainstones of shoal; 5 - coquinoid rudstone and floatstone; 6 - lithoclastic limestone; 7 - boundstone (reef limestone); 8 - open shelf nodular limestone; 9 - algae; 10 - oncolites; 11 - domal stromatolites; 12 - laminar stromatolites; 13 - continuous layer of laminar stromatolites; 14 - stromatoporoids; 15 - tabulate corals; 16 - discontinuity surface; 17 - mud-cracks.

Facies belts: I $a$ - lagoonal, I $b$ - restricted shelf, II - shoal, III - open shelf.

Beds: $J_{2} V$ - Vilsandi; $J_{2} M-M a a s i ; J_{2} T-$ Tagavere; $K_{1} V t-V i i t a ; K_{1} K n-$ Kuusnōmme; $K_{1} V_{S}-$ Vesiku; $K_{1} S n-$ Soeginina; $K_{2} S$ - Sauvere; $K_{2} H-$ Himmiste; $K_{2} U-$ Uduvere, 

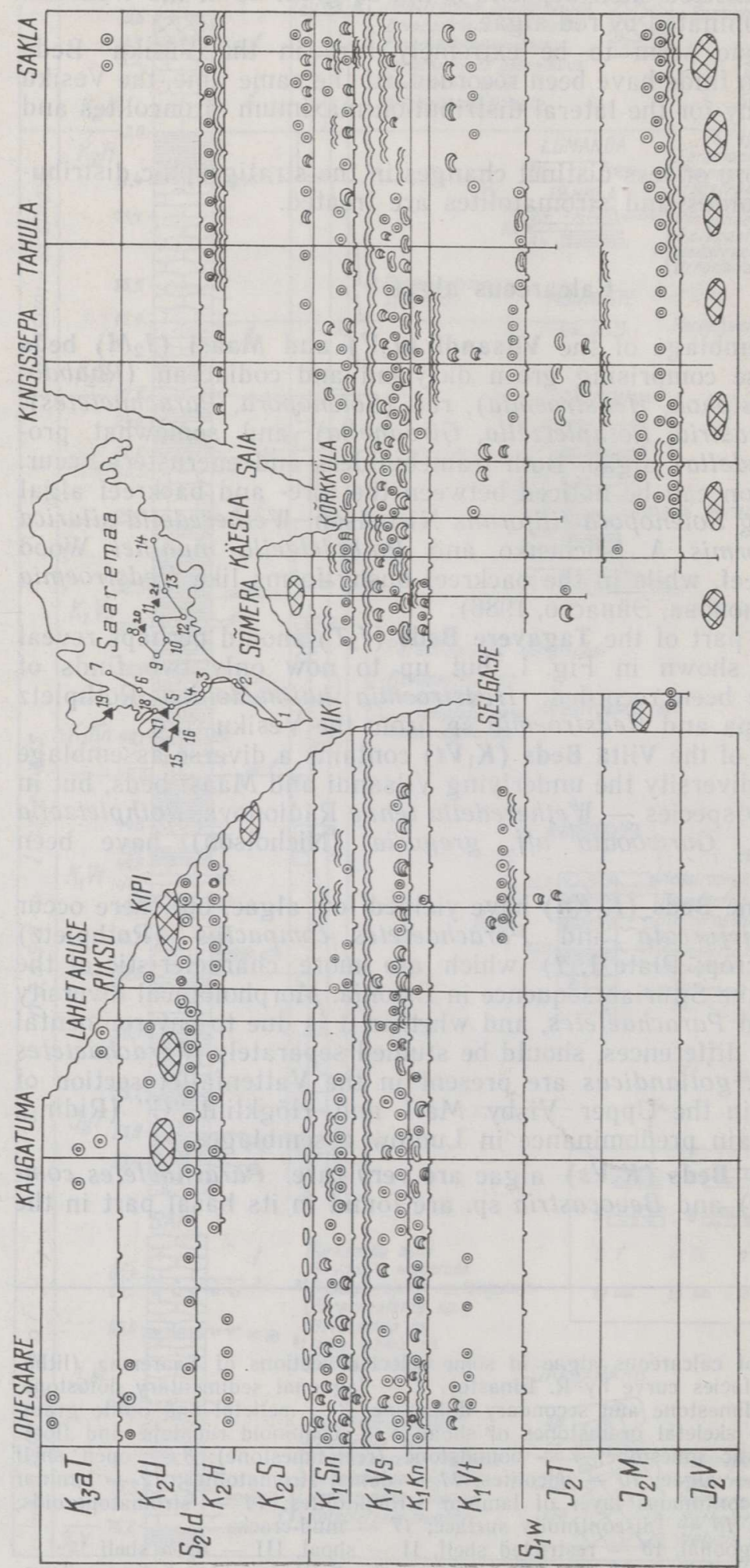

$1 \stackrel{0}{0}$ 문

..

잉

व $\infty \stackrel{\infty}{=}$

- is

…

की क

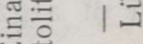

的

㛈吉新

- $1=$

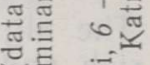

으

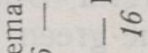

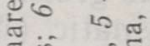

कूँ कै

$\equiv \div \quad \bar{\simeq}$

क ख 1 \%

잉

के

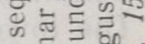

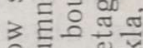
음 $\frac{1}{0} \div \frac{0}{0}$ ㅅ․

낭 的

ㄷํㅇ

웅유를 $3 E$ 近

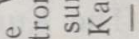
एक $>1 \%$ $\Xi \bar{\sigma}$ E. क्षे 11 . 문들 का som 110 政讨 ษँำ 풍유 넘 造क $-\infty=10$

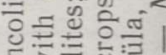

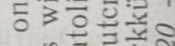
4 弥

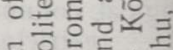
등하의 봉 능ำ 1 때을

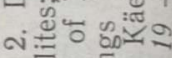

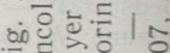


The red alga Parachaetetes compactus becomes abundant in the Soeginina Beds $\left(\boldsymbol{K}_{1} \boldsymbol{S} n\right)$. It occurs there as nodules or forms the nucleus of an oncolite (Soeginina cliff, Plate I, 3). Hedstroemia and Bevocastria have been distinguished in this unit in the Riiumäe core.

The Sauvere Beds $\left(\boldsymbol{K}_{2} \boldsymbol{S}\right)$ resemble the Soeginina ones as Parachaetetes compactus is still the commonest species in skeletal grainstones and boundstones of small reef-bodies. Parachaetetes is so abundant in Mõnnuste backreef grainstones that this limestone could be called " $\mathrm{Pa}$ rachaetetes limestone".

Starting with the Himmiste $\left(\boldsymbol{K}_{2} \boldsymbol{H}\right)$ and Uduvere $\left(\boldsymbol{K}_{2} \boldsymbol{U}\right)$ beds, the algal assemblage becomes diverse again. The Uduvere Beds contain Hedstroemia halimedoidea, Ortonella aff. furcata and Bevocastria amplefurcata. Parachaetetes gotlandicus is distinguished in the Uduvere Beds in the Saaremaa sequence for the first time. There exists a clear difference between Uduvere reefs and Maasi reefal deposits: the latter comprise green algae while in Uduvere reefs red algae predominate (Plate II, 1, 2, 3).

\section{Oncolites and stromatolites}

Oncolite accumulations representing the shallow high-energy environment occur in the Wenlock-Ludlow sequence in Saaremaa on 8 levels, the most remarkable of them appearing in the Maasi, Vesiku, Soeginina, and Himmiste beds (Fig. 2). Oncolites are usually distinguished only in the basal unit of the sedimentary cycle formed after a hiatus, but in the Vesiku and Soeginina beds oncolites are widespread also in the middle unit of a sedimentary cycle and absent only in the upper part - in Eurypterus dolostones (Радионова, Эйнасто, 1988). Vesiku oncolites occur on a vast territory, but having been deposited far from the open sea they do not contain algae. On the other hand, Soeginina oncolites have often a solenoporid nucleus or they contain filaments of Bevocastria in their outer layers.

The Vesiku Beds are remarkable also as their laminar stromatolite bed has the largest distribution area. Usually laminar stromatolites occur as lenses in the Silurian sequence in Estonia. In addition to laminar (in the Maasi, Viita, Soeginina, Himmiste beds) stromatolites, those of columnar and domal form (Plate II, 4) occur in the Vesiku Beds. The first domal stromatolites in the Wenlock-Ludlow sequence have been distinguished in the Maasi Beds, associating with discontinuity surfaces and overlain by grain- or packstones. Domal stromatolites seem to have been formed in high-energy and columnar stromatolites in subturbulent environment.

\section{Comparison and conclusions}

1. The diversity maximum of calcareous algae in the middle Wenlock, analogous with Estonia (Vilsandi, Maasi and lower Viita beds), can be seen in Podolia, the Urals (Чувашов, Шуйский, 1988), Quebec-Gaspé and Sayabec (Heroux et al., 1977). Only, green algae are not so abundant in Saaremaa sections as in Podolia or Quebec, where several species of Rhabdoporella, Dimorphosiphon and Ortonella have been found.

2. The Vesiku Beds contain tidal flat nonskeletal oncolites and widespread laminar stromatolites that might represent the deposits accumulated after the late Wenlock regression maximum, marked also by almost complete disappearance of calcareous algae. 
The low diversity of calcareous algae in Estonia and their absence in Podolia coincide at the level of the Rootsiküla Stage $\left(K_{1}\right)$ and the Ustje Subformation (note the different correlation by A. Ishchenko (Ищенко, 1985, Table 1)). The calcareous algal flora was replaced at the Rootsiküla Age by algal-microbial communities responsible for stromatolite formation. Non-calcified phaeophyte? algae like Buthotrepis found a suitable habitat in brackishwater lagoons.

3. The abundant solenoporids found in the Soeginina Beds might refer to the shoal environment with normalizing water circulation.

4. The algal assemblage of inner-shoal patch reefs of the Uduvere time was dominated by red algae Parachaetetes compactus and P. gotlandicus. The Ludlow assemblages are more diverse in Podolia and Quebec-Gaspé, both rhodo- and various chlorophytes occur there. A more diversified Ludlow assemblage (comparable to the one from Sokol reefs in Podolia) could be found in the East Baltic, perhaps, in the Piltene area, Latvia. The rise of diversity in the Ludlow is not so remarkable in shallow-water succession, but in Podolia the open shelf deposits have yielded a new green alga Sokolella and some other dasycladaceans.

A general tendency towards red algal dominance in the Ludlow can be observed in several regions (esp. Gaspé). Red algae seem to have been responsible for most of the calcareous algal biomass at the end of the Ludlow.

Acknowledgements. I am grateful to E. Radionova for supplying her collections and R. Einasto for helpful discussion on the topic. I thank D. Kaljo for his encouragement and critical reading of the manuscript.

\section{REFERENCES}

Bourque, P. A., Mamet, B., Roux, A. Algues Siluriennes du Synclinorium de la Baie des Chaleurs, Quebec, Canada. - Revue de Micropaléontologie, 1981, 28, N 2, $83-126$.

Heroux, Y., Hubert, C., Mamet, B., Roux, A. Algues Siluriennes de la formation de Sayabec (Lac Matapédia, Quebec). - Can. J. Earth Sci., 1977, 14, N 12, 28652908.

Kaljo, D. The Silurian of Estonia. - In: Field Meeting. Estonia 1990. An Excursion Guidebook. D. Kaljo, H. Nestor (eds.). Tallinn, 1990, 21-26.

Riding, R. Calcareous algae. - In: Lower Wenlock Faunal and Floral Dynamics Vattenfallet Section, Gotland. V. Jaanusson, S. Laufeld, R. Skoglund (eds.). Uppsala, 1979, 54-60.

Rothpletz, A. Uber die Kalkalgen, Spongiostromen und einige andere Fossilen aus dem Obersilur Gotlands. - Sver. Geol. Unders., 1913, Ser. C, N 10, 1-57.

Ищенко А. А. Силурийские водоросли Подолии. Киев, 1985.

Радионова Э. П., Әйнаста Р. Водорослевые сообщества венлока и лудлова Эстонии и их связь с фациями. - In: Теория и опыт экостратиграфии. Д. Кальо, Э. Клааманн (eds.). Таллинн, 1986, 163-185.

Радионова Ә. П., Эйнасто Р. Строматолиты и онколиты в карбонатных фациях ордовика и силура Прибалтики. - In: Известковые водоросли и строматолиты. В. Н. Дубатолов, Т. А. Москаленко (eds.). Новосибирск, 1988, 145-158.

Чувашов Б. И., Шуйский В. П. Стратиграфические и фациальные комплексы известковых водорослей Палеозоя Урала. - In: Известковые водоросли и строматолиты. В. Н. Дубатолов, Т. А. Москаленко (eds.). Новосибирск, 1988, 98-125.

Эйнасто P. Фациальные и палеогеографические условия образования эвриптеровых доломитов (силур Прибалтики). - In: Генезис и классификация осадочных пород. Междунар. геол. конгресс, XXIII сессия. Докл. сов. геологов. Москва, $1968,68-74$.

Presented by D, Kaljo

Received

Dec. 17,1990 


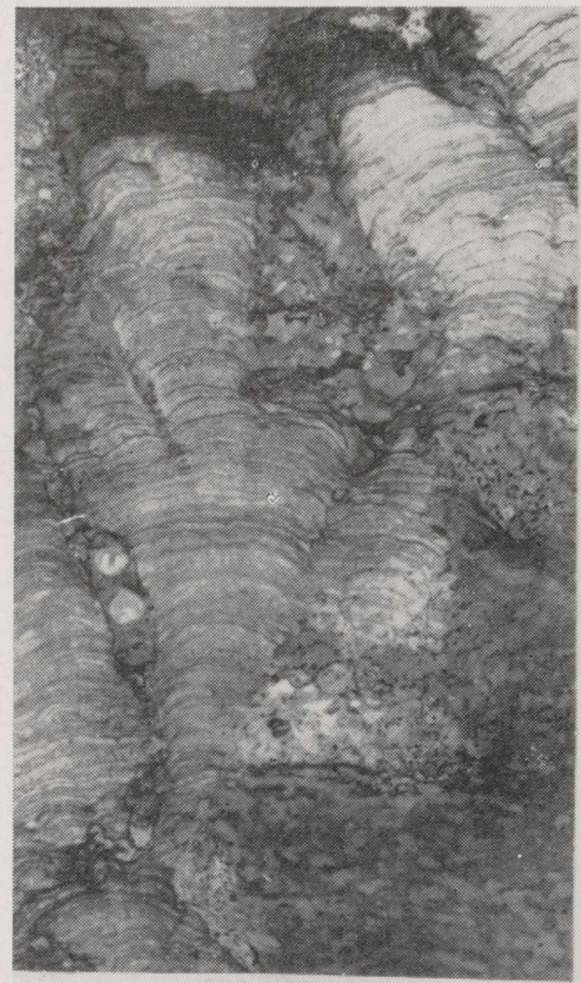

4
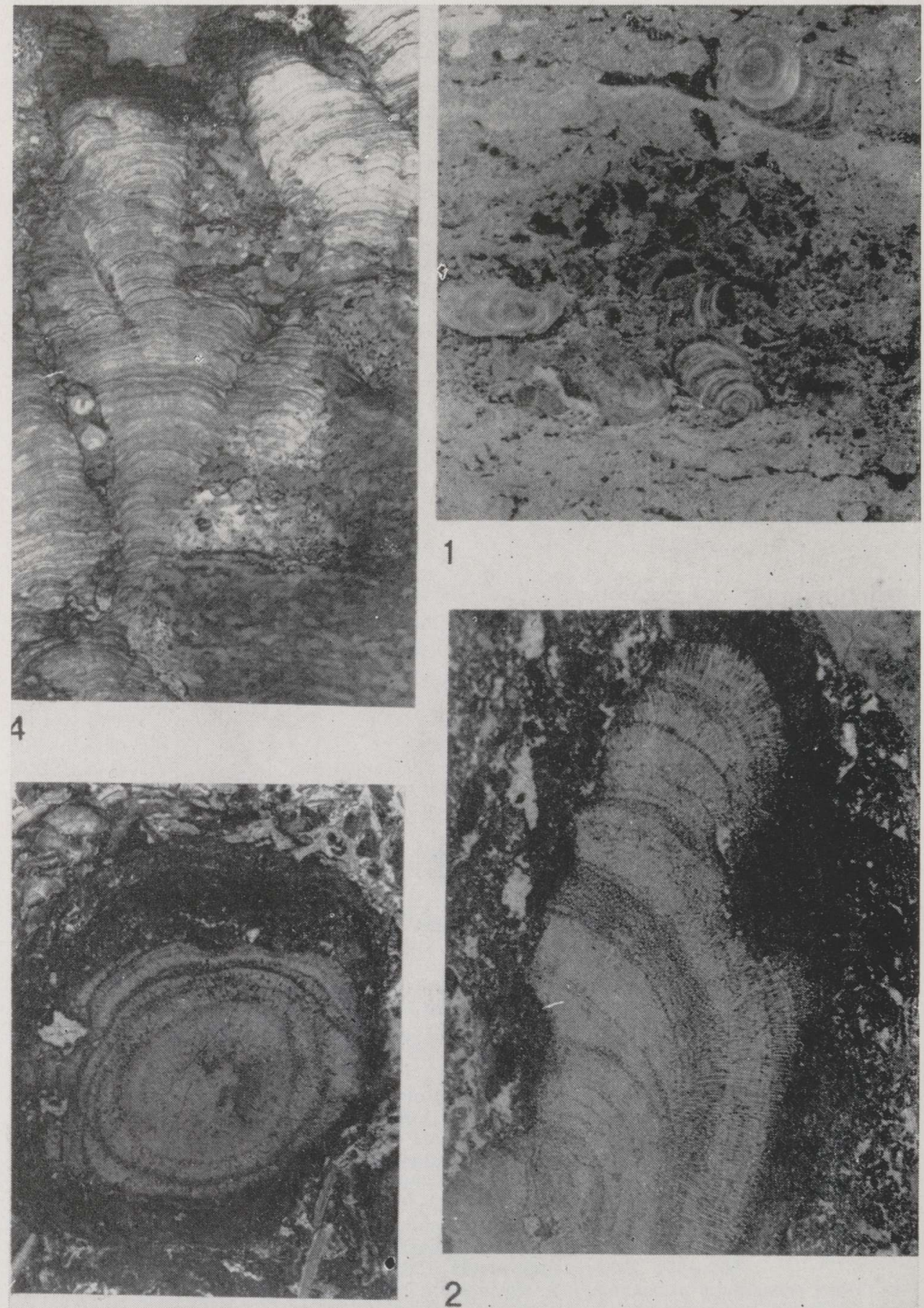

1

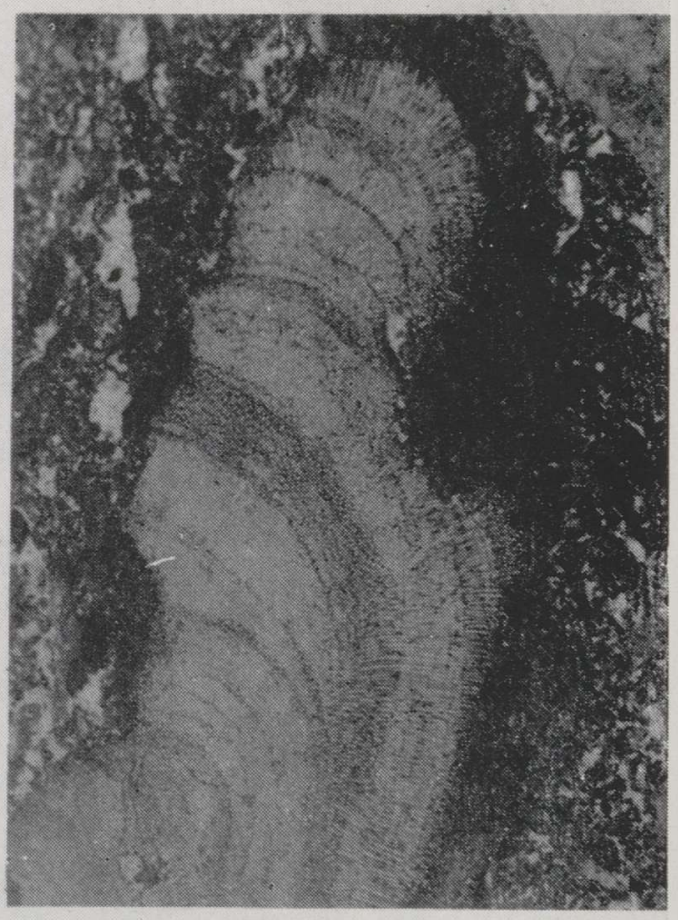

2

3

1 Specimens of Parachaetetes compactus (Rothpletz). $\times 1.2$. Kaarma core, $1.5 \mathrm{~m}\left(\mathrm{~K}_{2} \mathrm{H}\right.$, basal).

2 Parachaetetes compactus (Rothpletz). $\times 5.6$. Kaarma core, $1.5 \mathrm{~m}\left(K_{2} H\right.$, basal).

3 Parachaetetes compactus (Rothpletz). $\times 5.6$ Kipi core, $4.7 \mathrm{~m}\left(K_{2} U\right)$.

4 Columnar stromatolite. $\times 0.8$. Kaugatuma core, $79.7 \mathrm{~m}\left(K_{1} V s\right.$, basal $)$. 


\section{LUBIVETIKATE, ONKOLIITIDE JA STROMATOLIITIDE LEVIK WENLOCKI JA LUDLOW' PIIRIKIHTIDES EESTIS}

Artiklis on kokku võetud varem publitseeritud ja mõned uued andmed lubivetikate ja vetikmoodustiste (onkoliitide ja stromatoliitide) leviku kohta madalmerelise päritoluga setendites. Vilsandi ja Maasi kihtides ning Viita kihtide alumises osas esineb mitmekesine lubivetikate assotsiatsioon, mis kaob laguunsete setendite laialdasema ilmumisega läbilöikes (Viita kihtide ülemine osa). Onkoliitide ja stromatoliitide rohkus Vesiku kihtides ning solenoporiidsete punavetikate arvukus Soeginina kihtides viitab nimetatud kihtide transgressiivsele päritolule.

Aüле KЫPTC

\section{РАСПРОСТРАНЕНИЕ ИЗВЕСТКОВЫХ ВОДОРОСЛЕЙ, ОНКОЛИТОВ И СТРОМАТОЛИТОВ В ПОГРАНИЧНЫХ ОТЛОЖЕНИЯХ ВЕНЛОКА И ЛУДЛОВА В эсТОНИи}

Обобщены опубликованные и некоторые новые данные по распространению известковых водорослей и водорослевых образований (онколитов и строматолитов) в мелководных отложениях. Наиболее разнообразные ассоциации известковых водорослей приурочены к венлокским вильсандиским и маазиским слоям, а также к нижней части вийтаских слоев. Обилие онколитов и строматолитов в везикуских и увеличение численности соленопорид в соэгининаских слоях указывают на трансгрессивное происхождение этих отложений. 